\title{
Energy improvement in induction furnace using foaming slag with variation of carbon injection
}

\section{Theodore Mwata Kipepe}

\author{
Xiaowei Pan \\ Department of Extraction Metallurgy, University of Johannesburg, Johannesburg, South Africa
}

\begin{abstract}
Energy efficiency is nowadays one of the biggest concerns worldwide. It has become one of the critical matters to any country and industry particularly in South Africa. Because of the complexities and challenges found in industries and especially in foundry, many strategies have been established to measure and regulate more efficiently the energy. Many studies have been conducted in steelmaking process and electrical arc furnace using foaming slag to reduce energy consumption. As such, in this case study, the experiment will be conducted in a small foundry metal casting laboratory using an Induction Furnace (IF), which will reduce energy usage by using the foaming slag and as well pointing out the importance and the impact of carbon rate change on the foaming creation. After experiments all results show that the melting time can be reduced from $42 \mathrm{~min}$ to $35 \mathrm{~min}$, which is $20 \%$ time saving, the electrical energy consumption also has been reduced from $13.93 \mathrm{kWh}$ to $10 \mathrm{kWh}$ which is $39.3 \%$ saving. On the other hand, the foaming slag optimum height was reached at $1 \mathrm{~cm}$. Therefore, a simple modelling has been designed and calculations have been made on heat transfer at the surface opening of the Induction Furnace and temperature loss has been reduced from $878^{\circ} \mathrm{C}$ to $870^{\circ} \mathrm{C}$, with heat transfer loss reduced from $27.99 \mathrm{~kW}$ to $26.38 \mathrm{~kW}$ which was $6.10 \%$ of energy saving.
\end{abstract}

Keywords: energy efficiency, foaming slag, induction furnace, foundry metal casting

\section{Introduction}

For many years, trying to be energy efficient has become one of the first priorities all over the world. The energy efficiency goal is to reduce the amount of energy required to provide products and services (Wikipedia, 2014). The efficiency benefits can also be gained through environmental improvements.

More than ever, companies are facing increased competitive pressures to produce high quality products at equal or lower cost. With rising energy prices, companies are put under pressure to bring energy costs in line with standards of best practice. The efficiency is applied to all sectors so that they may be able to control and to use less energy by having a good result at the end of the process.

South Africa, for many years, is now facing very big challenges regarding energy consumption usage due to lower price of electricity which was a lack of motivation to save energy and has a negative effect of high energy usage (Rasmeni, 2014) (Figure 1). South African Industrial sectors (agriculture, mining, manufacturing and construction) are some of the biggest consumers of energy and use almost 45 to $49 \%$ of energy in South Africa (Davidson, 2006; Matlala, 2004). In the industrial sector, iron \& steel use $29 \%$ of energy in the industrial sub-sector (Davidson, 2006). Therefore, in the iron \& steel sector, foundries are the biggest consumers using different types of furnaces with the Induction Furnace known as the most efficient. Energy efficiency of any foundry largely rides on the efficiency of the melting process. Melting is the most energyintensive operation in the metal casting industry with $55 \%$ of the total energy in the foundries (Incorporated, 2005) (Figure 2). The induction heating process has been considered as high productivity, repeatable quality, and green heating technology compared to other fuel-fired furnaces (Dang, 2012).

The aim of this paper is to increase the efficiency of the Induction Furnace (IF) by using a foaming slag layer as insulation material to reduce the heat 


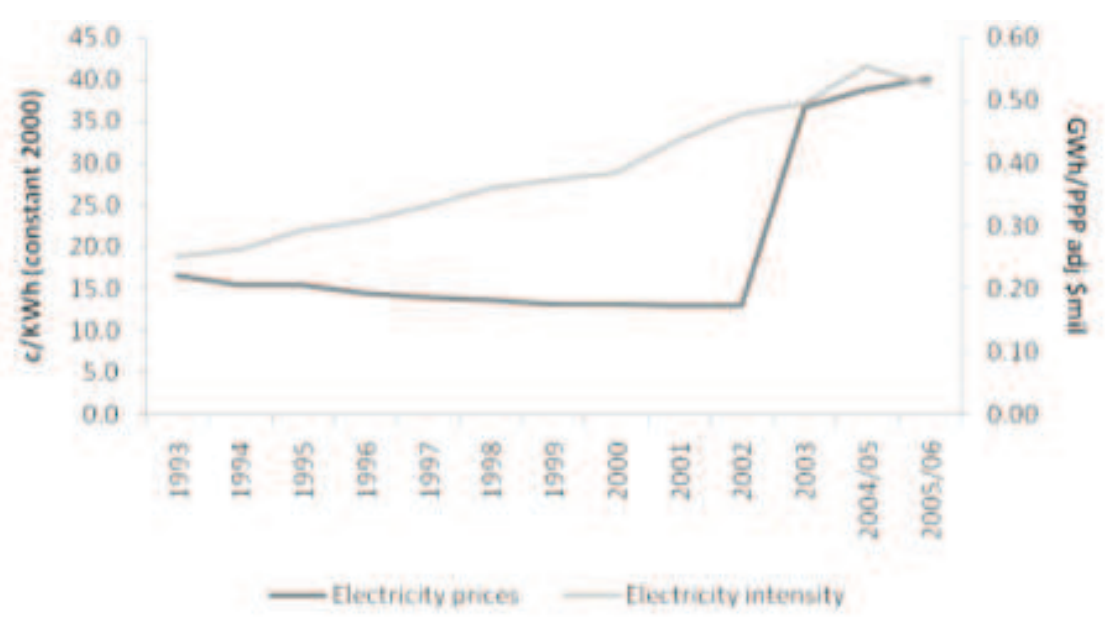

Figure 1: Electricity intensity and electricity prices in South Africa: 1993 to 2005

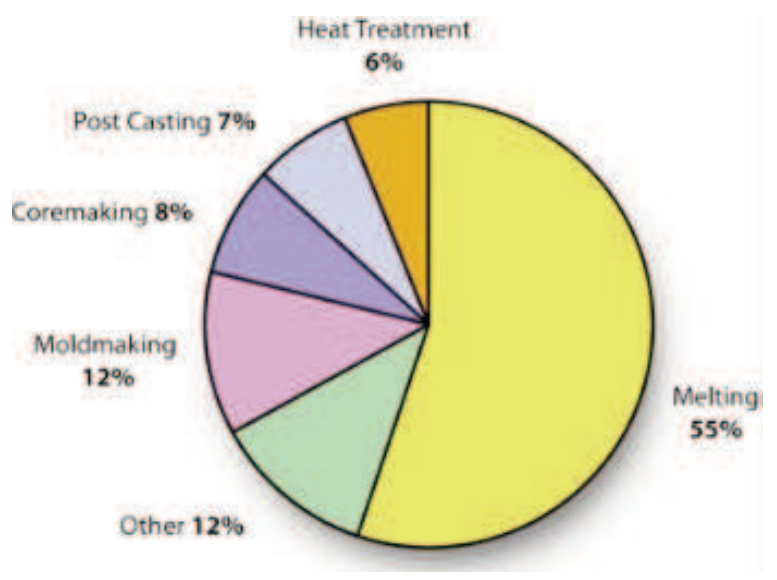

Figure 2: Melting operation as the most energyintensive operation in metal casting industry

loss at the opening of the Induction Furnace (Figure $3)$. The importance of this paper is to show the value of the carbon rate change in the creation of the foaming slag and the impact that it plays during this process on the energy efficiency procedure. The use of the foaming slag will decrease the heat loss, which will increase the efficiency of the furnace. As such, a Heat Transfer calculation will be conducted at the opening of the Induction Furnace to measure the heat loss during the process and to show the

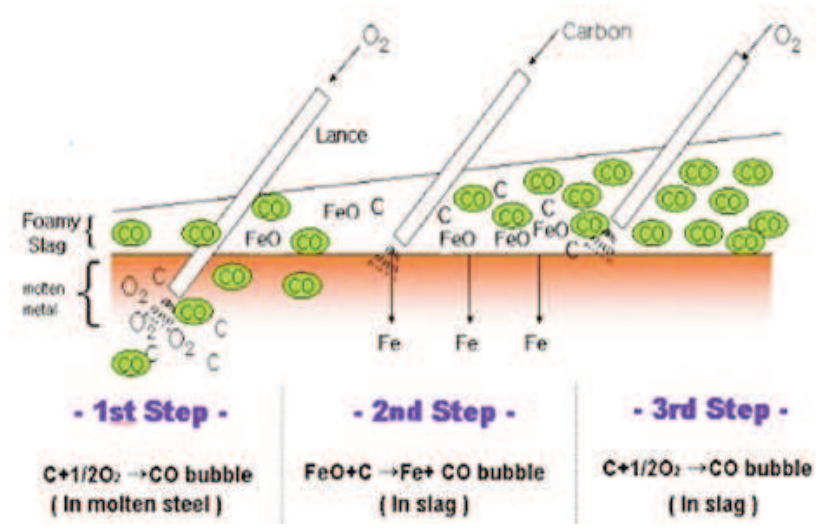

Figure 3: Mechanism of foaming slag creation

relation between the foaming slag and the heat transfer at the furnace opening.

\section{Experimental methods}

\subsection{Materials, apparatus and procedure}

For this investigation, the materials used were slag particles, oxygen gas, pure carbon particles and cast-iron scraps (Figure 4). In this paper, the experimental processes were done using a small laboratory Induction Furnace of $5 \mathrm{~kg}$, an electrical power
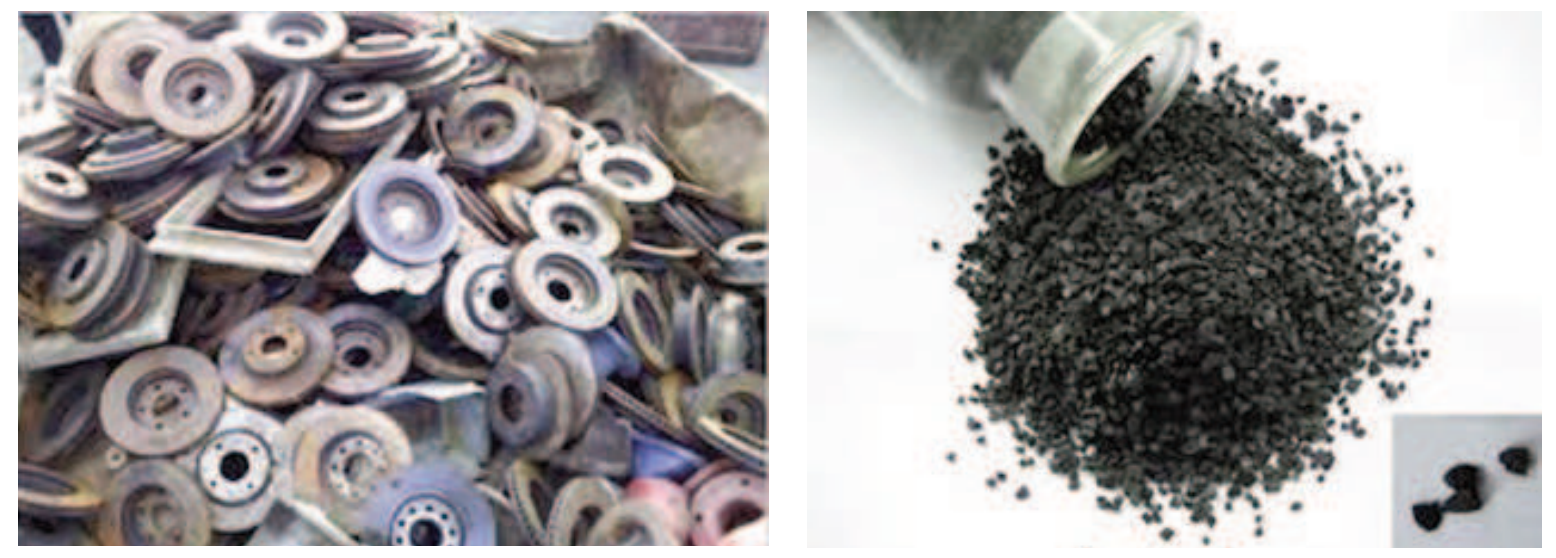

Figure 4: Cast-Iron scraps and carbon particles 
station (Figure 5), some alumina lances used to inject gas, a pyrometer to measure the temperature and a thermometer.
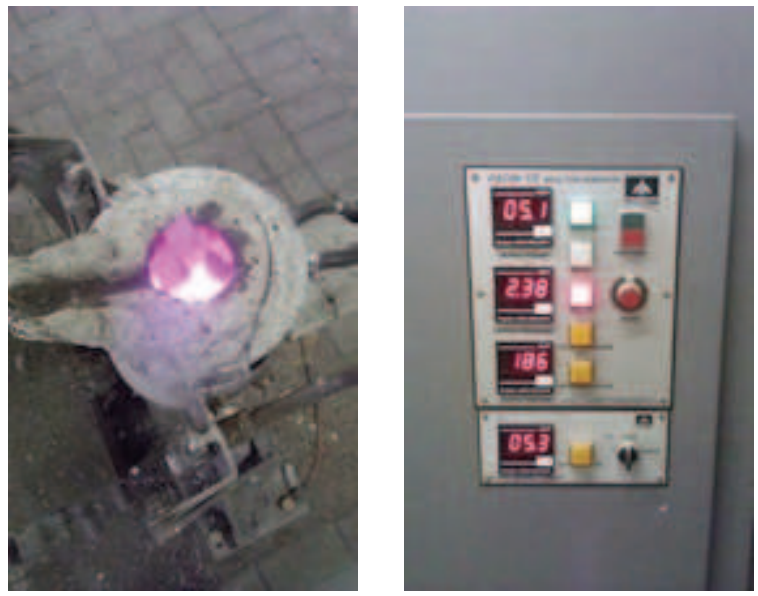

Figure 5: Laboratory induction furnace and electrical power station

Figure 5 shows the schematic diagram of the experimental procedure, which consists of 4 main steps.

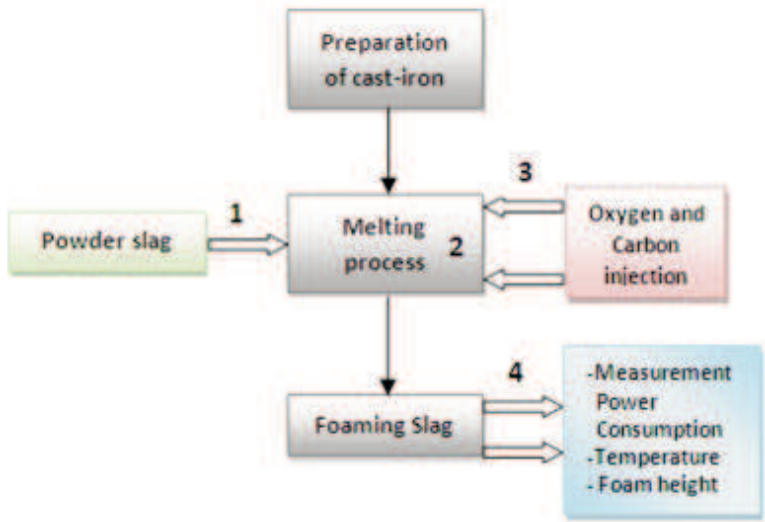

Figure 6: Schematic diagram of experiment procedure of foaming slag creation

Before any procedure, cast-iron scraps $(5 \mathrm{~kg})$ and the carbon particles in different weight of 21.27, 30, 35, 40, 45, and 55g were prepared. First step, the slag particles were poured into the crucible, followed by the cast-iron scrap reduced into small pieces and thereafter the laboratory's induction furnace was switched on.

At the temperature of $900^{\circ} \mathrm{C}$ when the cast-iron scraps are melting, the slag particles also melted and due to the difference of densities of the two melted elements, the slag has started floating and, at the same time, $100 \mathrm{ml}$ of oxygen gas is injected
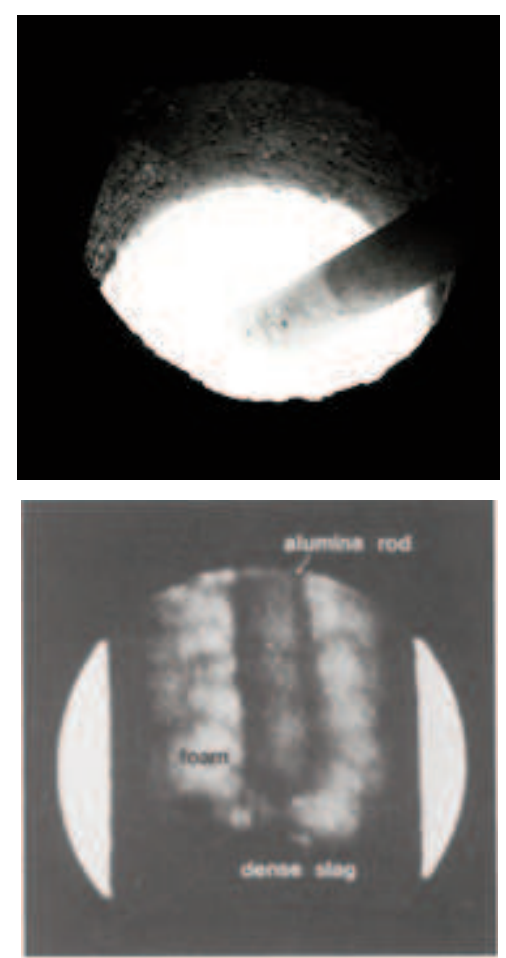

Figure 7: Overview of the measurement of height of the foaming slag using alumina rod

for 30 seconds into the molten. Thereafter, the carbon is now injected at $21.27 \mathrm{~g}$ for the first experiment and the procedure went on and on until the last $55 \mathrm{~g}$ of carbon was injected in the last experiment. The oxygen gas was injected for 30 seconds to ensure the reaction as shown in Figure 3 above. From the starting point until the measurement of the temperature on top of the foaming slag, the melting time and the power consumed were measured. The measurement of the height of the foaming slag was made by inserting an alumina rod into the molten and traces of the foaming slag left on the rod was allowing the reading of the height of the foam (Figure 7).

The melting process will be done using a preheated furnace for every experimental procedure due to the results obtained from the basic experimental procedure shown in Table 1.

\section{Results and discussion}

The results and discussion will give the influences of the carbon rate changes and its effect on parameters mentioned in Table 2.

\subsection{Influences of foaming slag height}

The carbon particles used in the melting process for

Table 1: Basic melting experimental processes for cold and pre-heated furnace

\begin{tabular}{lcccc}
\hline & $\begin{array}{c}\text { Melting time } \\
(\mathrm{min})\end{array}$ & $\begin{array}{c}\text { Electrical power }) \\
\text { consumption }(\mathrm{kWh}\end{array}$ & $\begin{array}{c}\text { Temperature } \\
\text { environment }\left({ }^{\circ} \mathrm{C}\right)\end{array}$ & $\begin{array}{c}\text { Heat transfer } \\
\text { rate }(\mathrm{kW})\end{array}$ \\
\hline Cast-iron cold furnace & 49 & 16.98 & 22 & 156.8 \\
\hline Cast-iron pre-heat furnace & 43 & 14.66 & 22 & 136.53 \\
\hline
\end{tabular}


Table 2: Variations of parameters during the experimental procedure

\begin{tabular}{ccccccccccc}
\hline & $\begin{array}{c}\text { Oxygen } \\
(\mathrm{ml} / \mathrm{sec})\end{array}$ & $\begin{array}{c}\text { Carbon } \\
(\mathrm{gr})\end{array}$ & $\begin{array}{c}\text { Foam } \\
\text { height }(\mathrm{cm})\end{array}$ & $\begin{array}{c}\text { Melting time } \\
(\mathrm{min})\end{array}$ & $\begin{array}{c}\text { Electrical power } \\
\text { consumption } \\
(\mathrm{kWh})\end{array}$ & $\begin{array}{c}\text { Temperature } \\
\text { surface of } \\
\text { foaming slag }\left({ }^{\circ} \mathrm{C}\right)\end{array}$ & $\begin{array}{c}\text { Temperature } \\
\text { of the } \\
\text { molten }\left({ }^{\circ} \mathrm{C}\right)\end{array}$ & $\begin{array}{c}\text { Heat } \\
\text { transfer } \\
\text { rate }(\mathrm{kW})\end{array}$ & $\begin{array}{c}\text { Percentages } \\
(\%)\end{array}$ \\
\hline 1 & 100 & 21.27 & 0.9 & 42 & 13.93 & 878 & 1275 & 32.62 & 38.21 \\
\hline 2 & 100 & 30 & 0.9 & 39 & 13.85 & 878 & 1269 & 31.89 & 38.16 \\
\hline 3 & 100 & 35 & 0.85 & 38 & 10.75 & 872 & 1263 & 30.23 & 37.20 \\
\hline 4 & 100 & 40 & 1.0 & 35 & 10 & 865 & 1261 & 29.7 & 36.01 \\
\hline 5 & 100 & 45 & 0.7 & 40 & 12.82 & 870 & 1271 & 29.3 & 36.86 \\
\hline 6 & 100 & 55 & 0.6 & 41 & 14.34 & 877 & 1265 & 28 & 38.06 \\
\hline
\end{tabular}

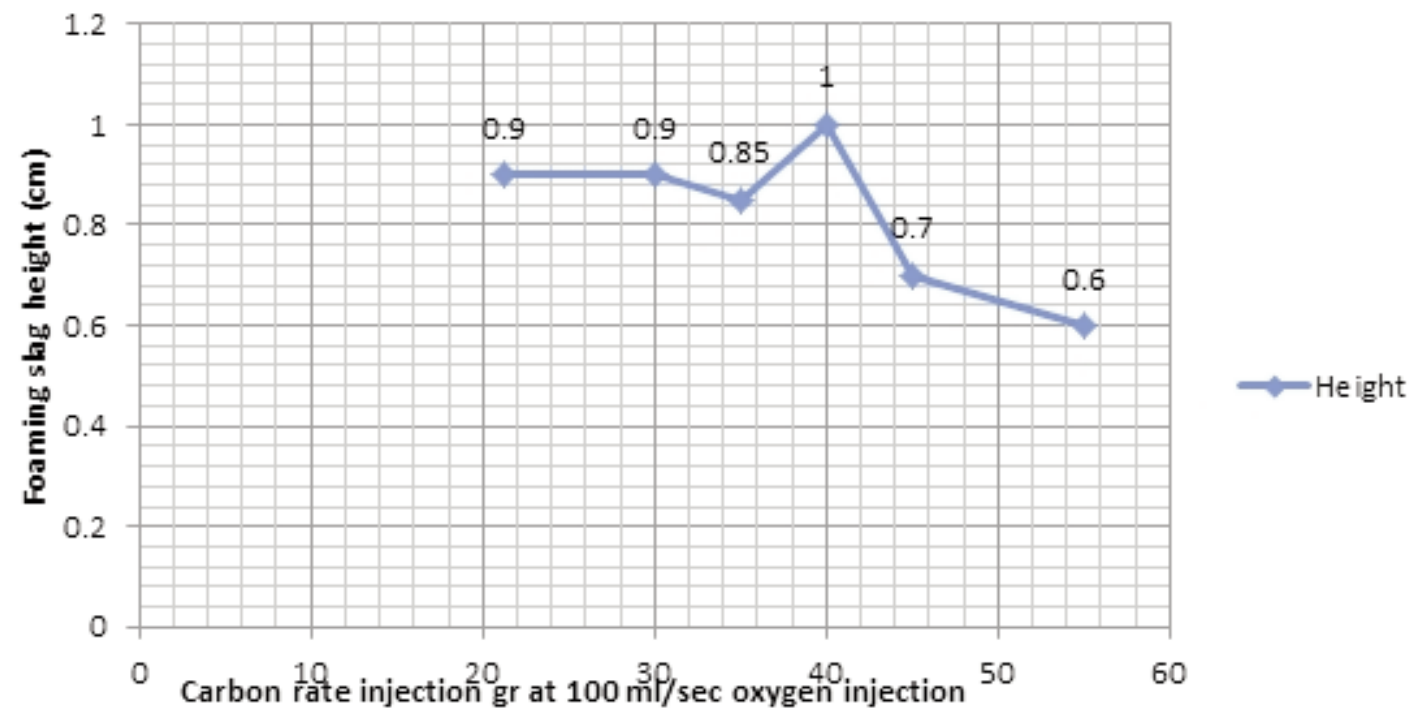

Figure 8: The effects of carbon rates variation on the foaming slag height

the foaming slag creation have been poured into the furnace at different rates from 21.27 to $55 \mathrm{~g}$. Figure 8 shows the variation of the height according to the carbon poured into the furnace; it also shows the height going up from $0.8 \mathrm{~mm}$ to $1 \mathrm{~cm}$ for $40 \mathrm{~g}$ of carbon poured. At $45 \mathrm{~g}$ and $55 \mathrm{~g}$, the height started to decrease due to carbon particles which were now in excess and started destroying the foaming slag that was already made.

At the optimum, the temperature at the surface was $878^{\circ} \mathrm{C}$, the melting time was 42 minutes and

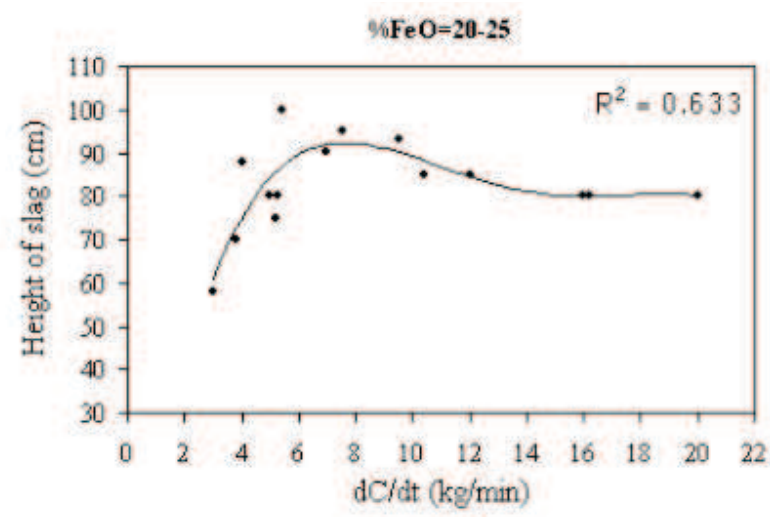

Figure 9: Variation of carbon injection rate with slag height

Source: Aminorroaya and Edris (2002) the optimum foaming slag height was $1 \mathrm{~cm}$, the electrical power consumption used was $13.93 \mathrm{kWh}$.

At $40 \mathrm{~g}$ of carbon poured in the molten, the reaction has reached the optimum and above this amount of carbon, the particles started destroying the bubbles because of the surface tension. A study conducted by Aminorroaya and Edris (2002) on the effect of foamy slag in electrical arc furnaces on electric energy consumption shows that the variation of carbon rate more than $9 \mathrm{~kg} / \mathrm{min}$ has no effect on slag foaming and increasing in electric energy consumption by increasing in melting time (Aminorroaya and Edris, 2002).

\subsection{Effect of melting time and temperature of the molten}

The melting time and the temperature of the molten during this operation were also influenced by the carbon that was poured into the molten during the procedure. Figures 10 and 11 show that increasing the carbon in the molten until a certain point was contributing to the oxidation which was exothermic and increasing the heat means decreasing the melting time of the cast-iron in the crucible.

Figure 10 shows that at $21.27 \mathrm{~g}$ the melting was $42 \mathrm{~min}$ and slightly increases for $1 \mathrm{~min}$ at $43 \mathrm{~min}$. But at $35 \mathrm{~g}$ and $40 \mathrm{~g}$, the melting time starts decreas- 


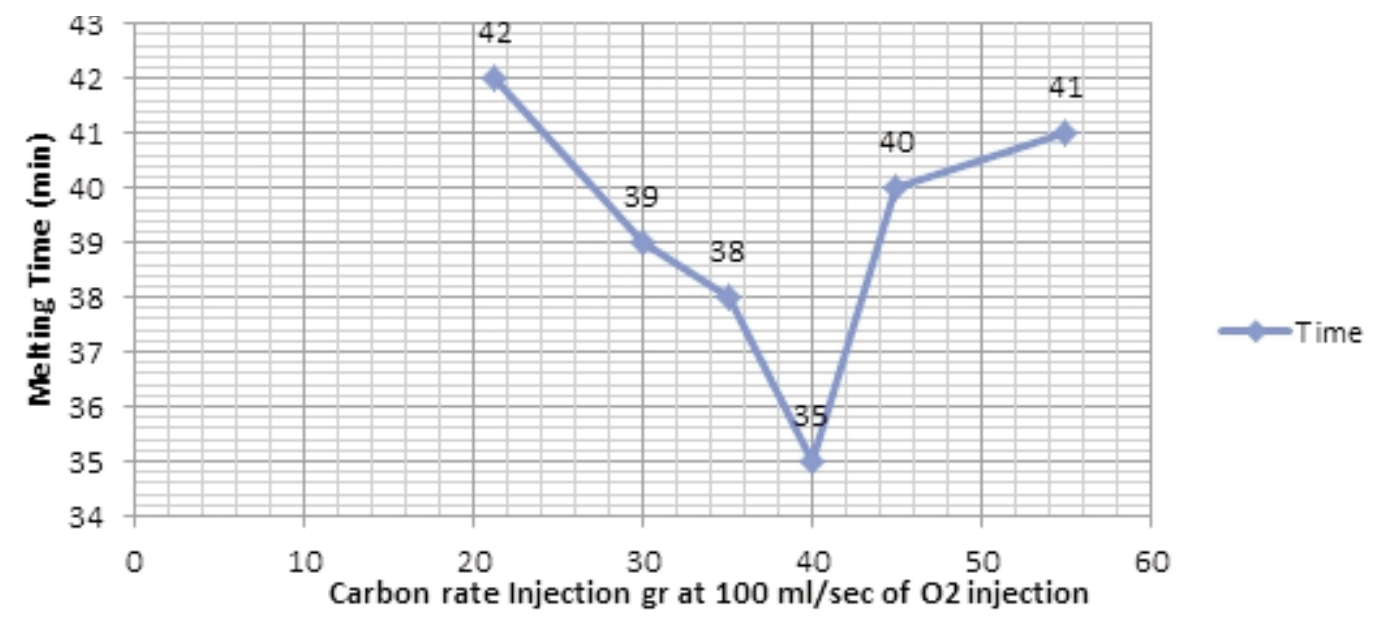

Figure 10: Influence of carbon rate on the melting time

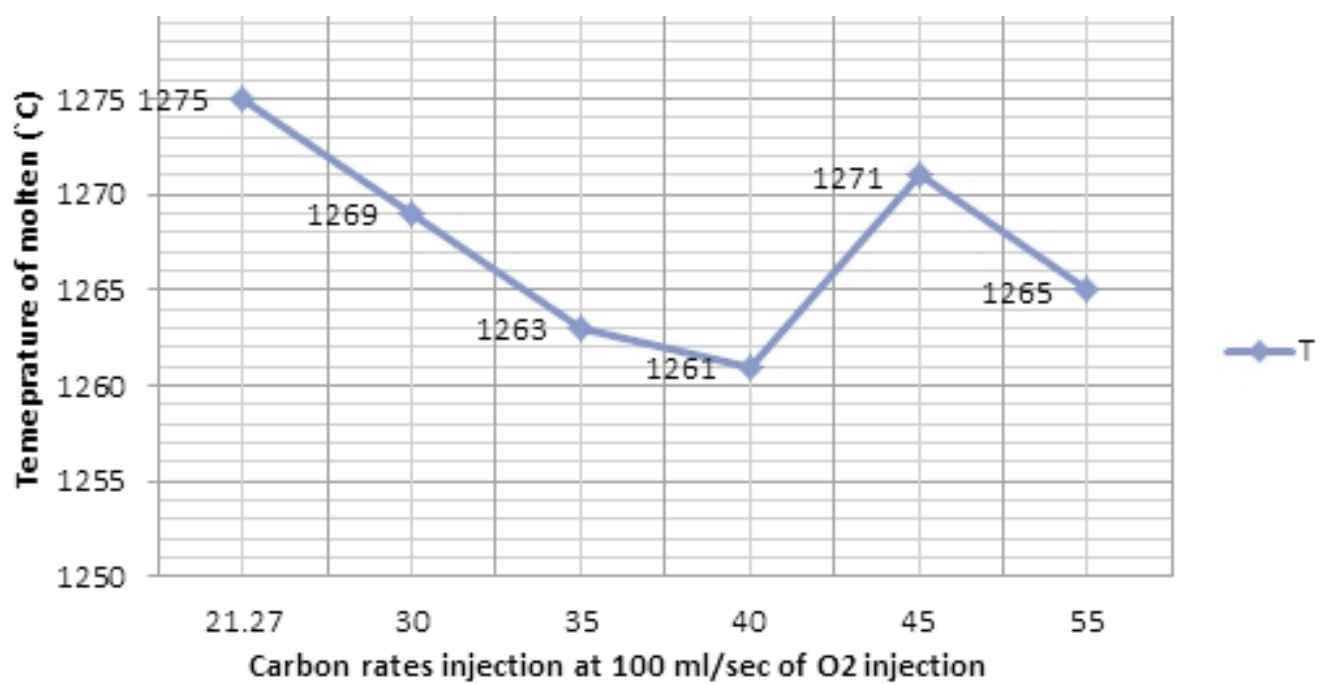

Figure 11: Influence of the carbon rate injection on the temperature of the melt

ing and the minima time was at $40 \mathrm{~g}$ of carbon poured into the molten. From $45 \mathrm{~g}$ until $55 \mathrm{~g}$, the melting time starts increasing again. During the melting process at $35 \mathrm{~g}$ and $40 \mathrm{~g}$ the oxygen gas injected at $100 \mathrm{ml} / \mathrm{sec}$ has reacted until the major percentage of carbon injected was consumed due the reaction. But at 45 and $55 \mathrm{~g}$, the oxygen gas at $100 \mathrm{ml} / \mathrm{sec}$ wasn't enough to oxidize all the carbon and that increases the time due the extra material added in the molten. But Figure 11 shows the relation between the temperature and the carbon rate injected in the molten from 21.27 to $40 \mathrm{~g}$, temperature was increasing due to the exothermic reaction which brought extra heat in the molten at $100 \mathrm{ml} / \mathrm{sec}$. But from 45 to $55 \mathrm{~g}$, heat was brought up and the rate of the oxygen could react with all the carbon particles poured in the molten. Ozturk and Fruehan have shown the impact of temperature on the foaming height. Foaming height on Figure 8 decreases with increasing the temperature (Fruehan, 1995). This shows the co-relation between the carbon and the temperature during the melting process.

\subsection{Influence of electrical energy consumption}

During the reading of electrical power, the carbon rate injection has shown some variation during the process. In fact, some other parameters have played an important role in the reduction of electrical energy consumption such as the basicity of the slag (Aminorroaya and Edris, 2002). Figure 12 shows the variation of the electrical power consumption. From $21.27 \mathrm{~g}$ to $40 \mathrm{~g}$, the electrical energy went down and slightly started increasing from 40 to $55 \mathrm{~g}$.

Therefore, from $21.27 \mathrm{~g}$ to $40 \mathrm{~g}$ the room temperature was $23^{\circ} \mathrm{C}$ and from 40 to $55 \mathrm{~g}$ room temperature was $9^{\circ}$ less than normal. Room temperature also played a part on the heating process of the material, the time and eventually on the energy needed to heat the cast-iron. Figure 13 shows that the electrical energy consumption varies with the foaming slag height. If the foaming slag height increases, the electrical energy consumption decreases (Aminorroaya and Edris, 2002).

Aminorroaya and Edris (2002) have also stud- 


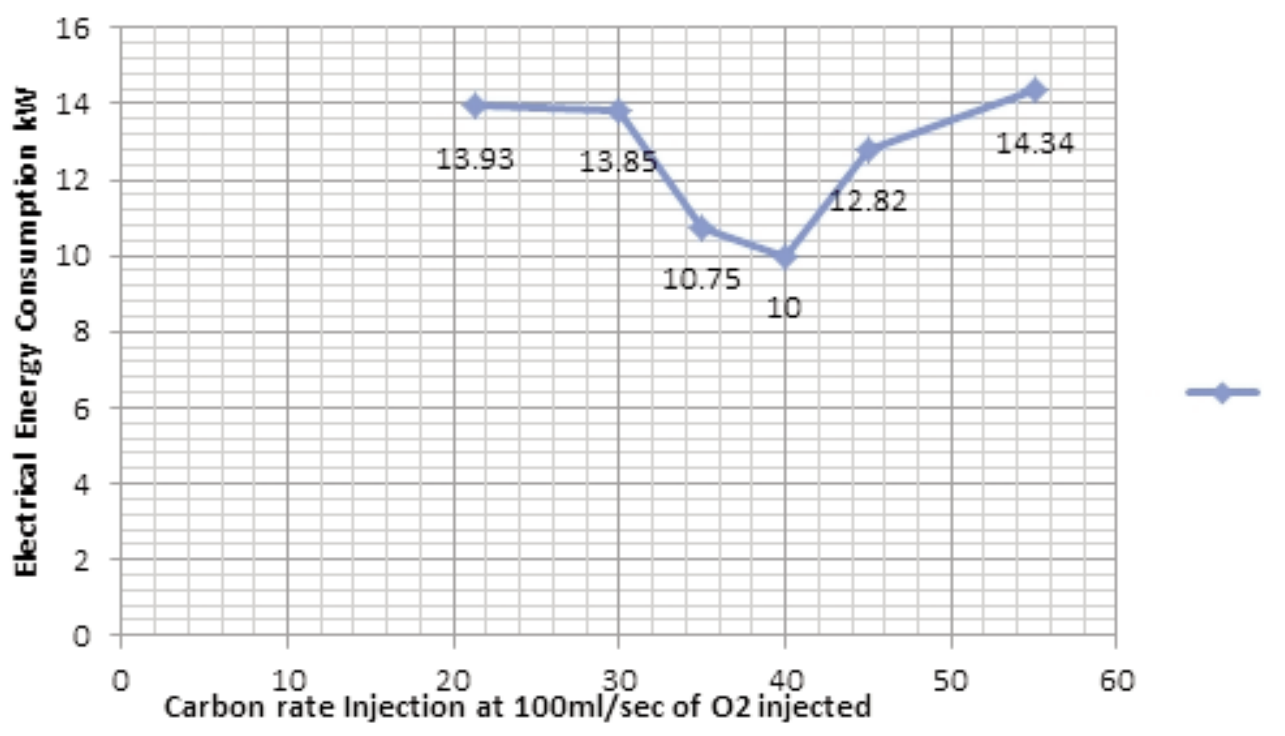

Figure 12: Influence of carbon rate injection on the electrical energy consumption kW

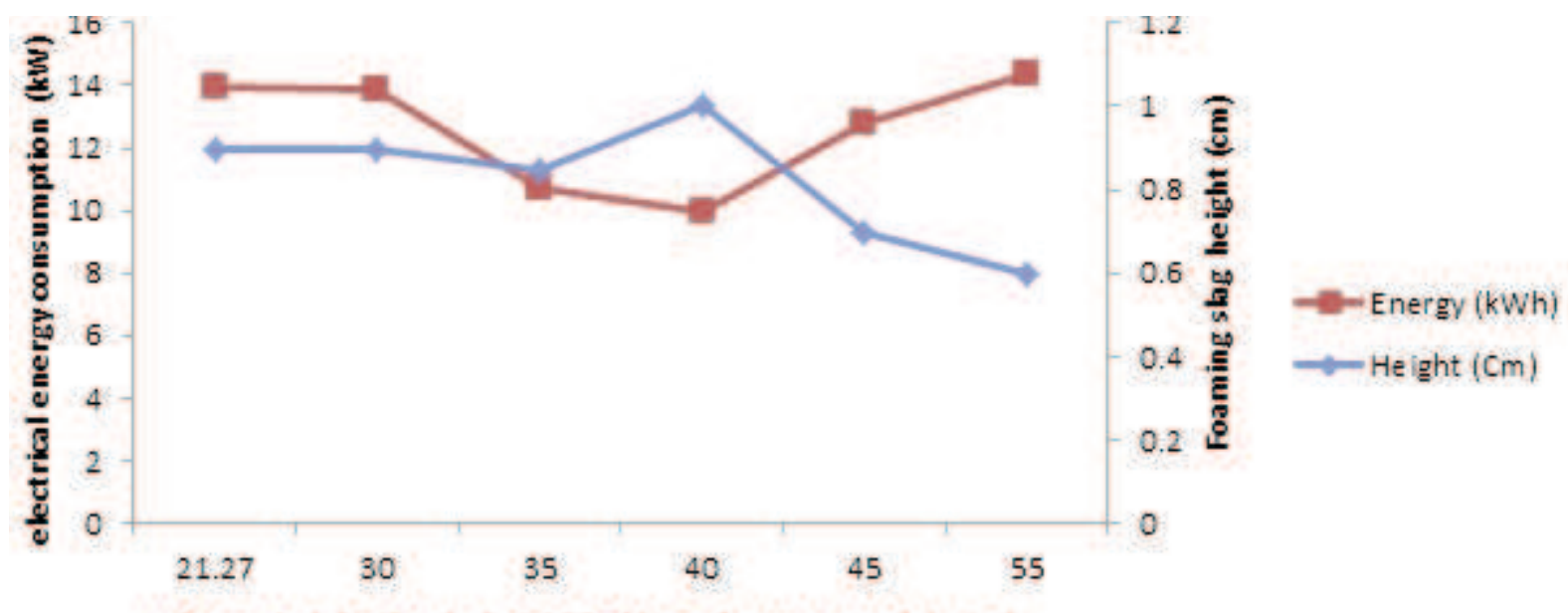

carbon rate injection (gr) at $100 \mathrm{ml} / \mathrm{sec}$ of oxygen gas injected

Figure 13: Relationship between the electrical energy consumption and the foaming slag height $(\mathrm{cm})$

ied and found the influence of the carbon rates on the electrical energy consumption and during their experience, electrical energy decreased with increasing carbon injection rate up to $9 \mathrm{~kg} / \mathrm{min}$.

\subsection{Influence of surface temperature of the foaming slag}

The temperature determination on the surface of the foaming slag has all to do with the thickness of the foaming slag and the contribution of the carbon particles. The foam creation is one of the major elements during the process.

Figure 15 shows that from $21.27 \mathrm{~g}$ to $40 \mathrm{~g}$ the temperature decreases due to the carbon rate, which influences the foaming slag height, and increases the thickness of the foaming slag. Increasing the thickness means increasing the height which decreases the heat loss on top of the furnace (Figure 16). At $45 \mathrm{~g}$ and $55 \mathrm{~g}$, the temperature starts increasing due to the fact that the foaming slag

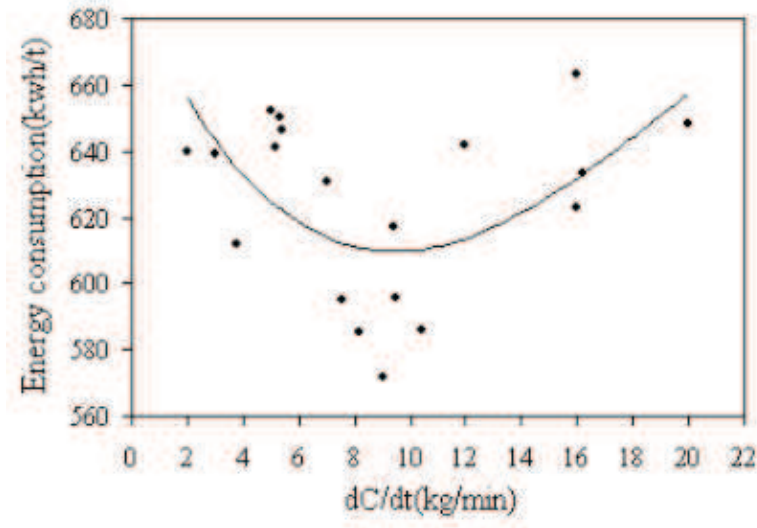

Figure 14: Variations of carbon injection rate with electrical energy consumption

Source: Aminorroaya and Edris (2002)

started to be destroyed due to the excess of carbon particles in the molten. The carbon particles reacted with the bubble and start destroying them and as 


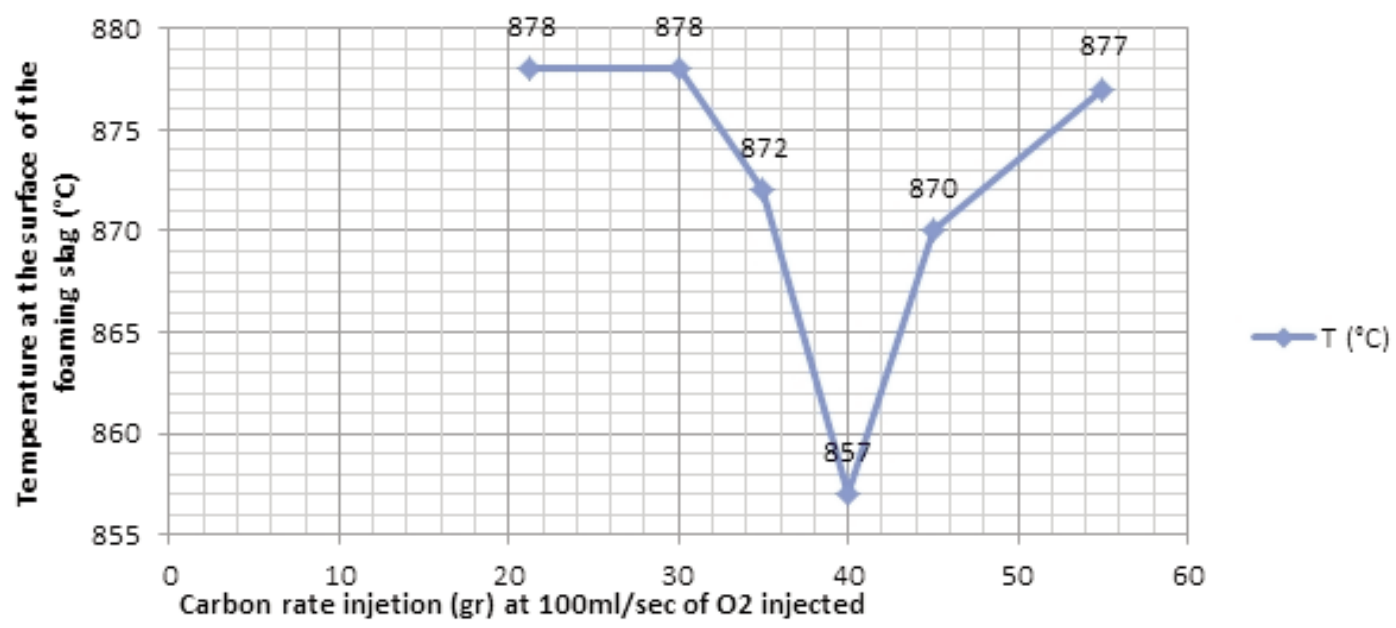

Figure 15: Influence of carbon rate injection $(\mathrm{g})$ on the surface temperature of the foaming slag $\left({ }^{\circ} \mathrm{C}\right)$

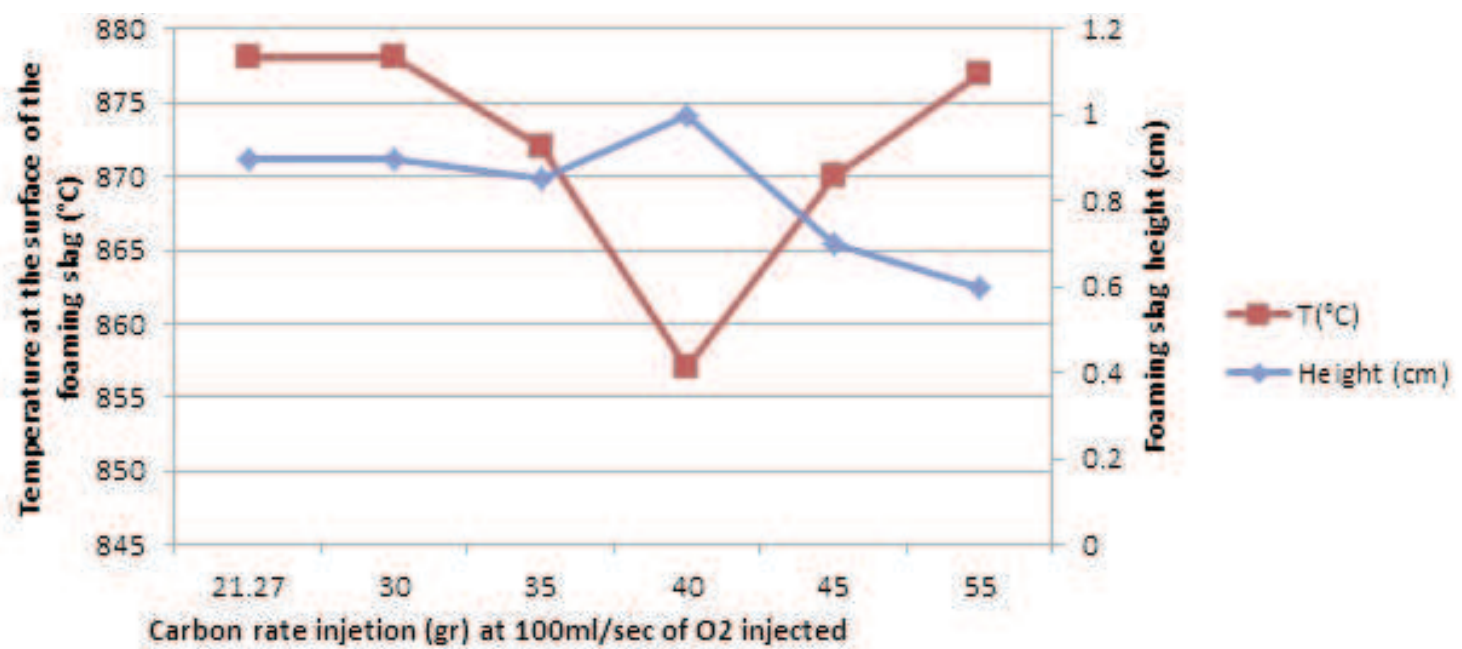

Figure 16: Relationship of temperature at the surface of the foaming slag with the foaming slag height at different carbon rate injection

such decreasing the foam height (Y. Zhang, 1995). The surface temperature of the foaming slag has also everything to do with the foaming height thickness.

\subsection{Heat transfer calculation}

The heat transfer in the induction furnace is located and comes from the metal to be heated. The thermal transfer is done to the wall and to the top or opening of the furnace. An Induction furnace is a made of a crucible in graphite, some coils cooled by water circulation (Mauricio V. Ferreira da Luz, 2010). Those coils are protected by an insulation material or refractory.

For a better understanding of the furnace, modelling should be done to see which part of the furnace might be influencing the calculation. The choice of the domain is very important because it shows and gives the kind of heat applied for. The aim is to find some domains which will influence and show which types are used: conduction, convection and radiation. Our focus will be on the thermal problems. Figure 17 gives us a sketch of the fur-

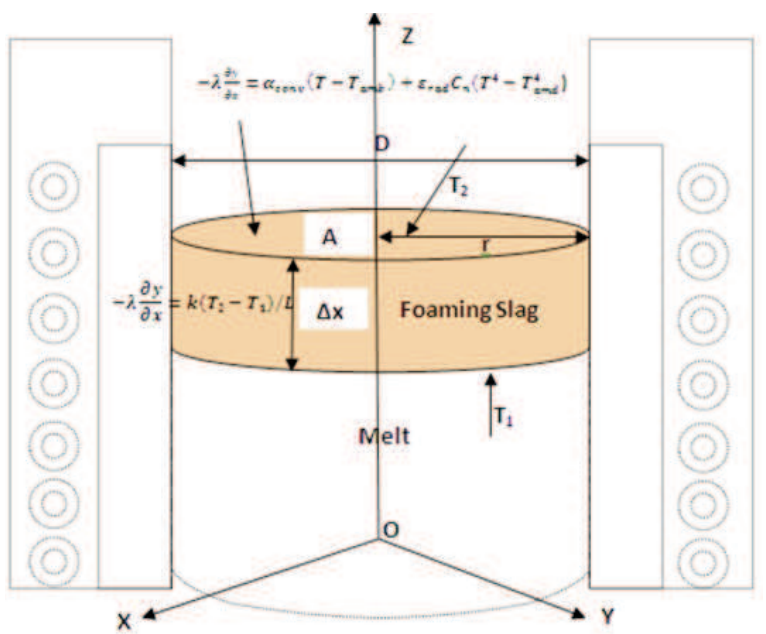

Figure 17: Sketch of the induction furnace

nace and the possible heat and domain which needs to be measured.

The calculus domain in our case will only be focused on the thermal problem, the inductor region will be considered as one single core and the 
calculation will be done according to that.

The boundaries of the calculus domain are in fact the surface through that thermal transfer from the furnace parts to the surroundings.

At the surface of the furnace the domain will be given by and the heat transfer is a combination of convection and radiation:

$$
-\lambda \partial y / \partial x=\alpha_{\text {conv }}\left(T-T_{\text {amb }}\right)+\varepsilon_{\text {rad }} C_{n}\left(T^{4}-T^{4}{ }_{\text {amb }}\right)[1]
$$

Where, $\alpha_{\text {conv }}$ is the convection coefficient. $\varepsilon_{\text {rad }}=$ 0.83 is the total emissivity and $C_{n}=5.67 .10^{-8}$ $\mathrm{W} / \mathrm{m}^{2} \mathrm{~K}^{4}$ is Stephan constant, $\mathrm{T}$ is the surface temperature, $T_{\text {amb }}$ is the temperature of surrounding environment. The coefficients $\alpha_{\text {conv }}$ and $\varepsilon_{\text {rad }}$ could depend on temperature and $\varepsilon_{\text {rad }}$ could depend in addition on surface quality.

If the heat transfer calculation in the inductor must be done, the convection heat transfer should be considered because of the exchange between the inductor and the cooling water that circulate through the coils and it given by:

$$
-\lambda \partial \mathrm{y} / \partial \mathrm{x}=\alpha_{\text {convind }}\left(\mathrm{T}-\mathrm{T}_{\text {medapa }}\right)
$$

Where $\alpha_{\text {convind-apa }}$ is the transmissivity between the inductor and cooling water whose medium temperature is $T_{\text {med apa }}$ (Pasca, 2004). In this case the temperature of the molten, the surface temperature on top of the foaming slag has been considered in Table 2: At the Interface melt and foaming slag the heat transfer is made by conduction:

$$
-\lambda \partial \mathrm{y} / \partial \mathrm{x}=\mathrm{kA}\left(\mathrm{T}_{2}-\mathrm{T}_{1}\right) / \mathrm{L}
$$

Where $\mathrm{k}$ is the thermal conductivity, $\mathrm{A}$ is the surface of cylinder; $\mathrm{L}$ is the length of the layer.

During the calculation the $\triangle \mathrm{X}$ changes according to the height of the foaming slag which influences the heat transfer operation.

The total heat transfer loss during the process on top of the furnace will be influence by the conduction, convection and radiation:

$$
\begin{aligned}
& -\lambda \partial y / \partial \mathrm{x}=\alpha_{\text {conv }}\left(\mathrm{T}-\mathrm{T}_{\mathrm{amb}}\right)+\varepsilon_{\text {rad }} \mathrm{C}_{\mathrm{n}}\left(\mathrm{T}^{4}-\mathrm{T}_{\text {amb }}^{4}\right)+ \\
& \mathrm{kA}\left(\mathrm{T}_{2}-\mathrm{T}_{1}\right) / \mathrm{L}
\end{aligned}
$$

The influence of surface of the cylinder $A$ in this case will be influenced by the height of the foaming slag and represented by $L$ :

$$
\begin{aligned}
& \mathrm{A}=\pi\left(\mathrm{D}^{2} / 4\right) \mathrm{L}=\pi \mathrm{r}^{2} \mathrm{~L} \\
& \mathrm{~A}=\pi\left(\mathrm{D}^{2} / 4\right) \mathrm{L}=3.14 \times 0.05^{2} \mathrm{~L}
\end{aligned}
$$

$$
\mathrm{A}=0.00785 \mathrm{~L}
$$

The measurement of the heat transfer will depend on the variation of the thickness of the foam. As such, the results will show the variation of the heat according to the foaming height. The calculation has been made according to the equation 4 :

$$
\begin{aligned}
& -\lambda \partial y / \partial x=19.10 \times(878-23)+0.83 \times 5.67 .10^{-8} \\
& \left(878^{4}-23^{4} \text { env }\right)+0.15 \times \pi \times 0.0025(1265-878) \\
& -\lambda \partial y / \partial x=27.99 \mathrm{~kW}
\end{aligned}
$$

All the results are shown on Table 2 which is the table of variations. The heat transfer calculation for the basic experiments without any kind of foam or insulation has been considered as such the calculation was given by the formula in equation 10. The conduction was considered as zero because the temperature at the interface was the same solid (molten) and the gas.

$$
\begin{aligned}
& -\lambda \partial y / \partial x=19.10 x(1905-23)+0.83 x \\
& 5.67 .10^{-8}\left(878^{4}-23^{4}{ }_{\text {env }}\right)+0 \\
& -\lambda \partial y / \partial x=136.5 \mathrm{~kW} \text { for cold furnace and; } \\
& -\lambda \partial y / \partial x=156.8 \mathrm{~kW} \text { for preheated furnace. }
\end{aligned}
$$

During the carbon injection into the molten, the reactions below are exothermic because they increased the temperature into the furnace $(\mathrm{N}$. Sahay, June 2014) (Pandey, 2003).

$$
\mathrm{C}+\mathrm{O}_{2}=\mathrm{CO}_{2}+24.03 \mathrm{Kcal} / \mathrm{g} \text { mole }\left(\mathrm{T}<800^{\circ} \mathrm{C}\right)
$$

$$
\mathrm{C}+1 / 2 \mathrm{O}_{2}=\mathrm{CO}+26.42 \mathrm{Kcal} / \mathrm{g} \text { mole }\left(\mathrm{T}>800^{\circ} \mathrm{C}\right)
$$

Figure 18 gives the variation of the heat loss compare to the height of the foaming; the figure shows that $1 \mathrm{~cm}$ was the optimum height reached during the process. From $0.9 \mathrm{~cm}$ the foaming height stays a little bit constant. When the height increases the heat loss decreases due to the thickness of the foam which reduces the heat loss.

\section{Conclusion and summary}

The importance of energy efficiency has been demonstrated during the experimental procedure. This paper illustrated the importance of the foaming slag during the melting process and the utility of the foaming slag during the heat loss. The results of the experiments and observations revealed that:

1. At $40 \mathrm{~g}$, the use of the foaming slag in the induction furnace has given a melting time saving of 5 minutes which is almost $17.15 \%$ of time.

2. The electric energy consumption has been saved from $13.93 \mathrm{~kW}$ to $10 \mathrm{~kW}$ at $39.3 \%$ of electricity energy. At $40 \mathrm{~g}$ of carbon injected, the 


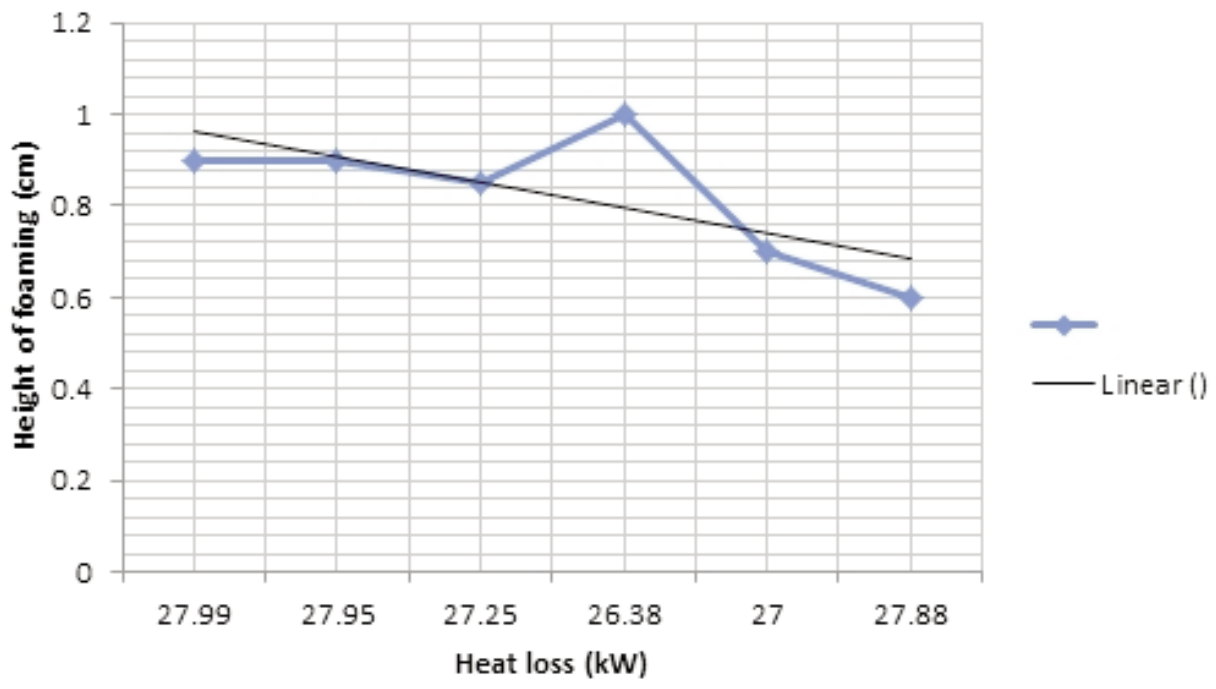

Figure 18: Relation of heat loss with height of foaming

foaming slag obtained its optimum at the height of $1 \mathrm{~cm}$.

3. The foaming slag insulation has helped reduce the temperature radiation from $878^{\circ} \mathrm{C}$ to $870^{\circ} \mathrm{C}$. The thickness of the foam creates a layer which could reduce the heat loss.

4. The heat transfer calculation during the parameters change shows a variation of the heat loss due to the height (Figure 18). The graph line goes down with the heat loss decreasing and that means if the height decreases the heat loss increases. The heat transfer loss during the calculation gives a variation of temperature from $27.99 \mathrm{~kW}$ to $26.38 \mathrm{~kW}$, which give a saving of $6.10 \%$.

5. Comparing the basic experimental heat loss $(136.53 \mathrm{~kW})$ with the heat loss during the foaming slag $(26.38 \mathrm{~kW})$ creation almost shows the importance of using foaming slag during the process because in this case, using foaming slag reduces the heat loss to $110,15 \mathrm{~kW}$ which is almost $19.4 \%$ of the energy loss.

6. Usage of foaming slag in the induction furnace in this experiment shows that the foaming slag is theoretically and practically efficient but coming to the heat transfer a tremendous heat loss occurred due to the thickness of the foaming slag, which was very tiny and instead of reducing more heat radiation its reduces less.

7. The improvement of the induction furnace using carbon injection parameters in this research can be implemented to the actual furnaces and not only to the Lab situation.



Figure 19: Comparison and variation of heat transfer $(\mathrm{kW})$ and foaming slag height $(\mathrm{cm})$ due to carbon rate injection at $100 \mathrm{ml} / \mathrm{sec}$ oxygen 


\section{Acknowledgments}

The authors gratefully acknowledged the support of the University of Johannesburg's Foundry Laboratory of Doornfontein Campus for the realization of this project. Our thanks go to the Laboratory technician assistant, Mr. Gilbert. for his availability, time and assistance.

\section{References}

Agency, I. E. (2012). Worldwide engagement for sustainable energy strategies. Germany: International Energy Agency.

Aminorroaya, S and Edris, H. (2002). the effect of foamy slag in the electrical arc furnaces on the electric energy consumption. 7th European Electric Steelmaking Conference (pp. 2.447- 2.456). Venice: 7th European Electric Steelmaking Conference.

Dang, H.-S. P.-P. (2012). Optimization of the In-line induction Heating Process for Hot Forging in Terms of Saving Operating Energy. International Journal of precision engineering and manufacturing , 13 (1085), 1085-1093.

Fruehan, B. O. (1995). Effect of Temperarute on slag foaming. Metallurgical and Materials Transactions B, 26B, 1086- 1088.

Fruehan, B. O. (1995). Effect of temperature on slag foaming. Metallurgicall and Materials Transactions B, 26B, 1086.Fruehan, K. I. (1989). Study on the foaming of $\mathrm{CaO}-\mathrm{SiO} 2-\mathrm{FeO}$ slags: Part 1. Faoming

parameters and experimental results. Metallurgical Transaction B, 20B, 509- 511.

Incorporated, B. (2005). Advanced Melting Technologies: energy savings concepts and opportunities for the Metal Casting Industry. Columbia, MD: U.S Department of Energy Energy Efficiency and renewable Energy.

Matlala, T. (2004). Demand Side Management Implementation in South Africa.: Eskom.

Mauricio V. Ferreira da Luz, A. B. (2010). Modeling of a Crucible Induction Furnace Taking Into Account the Inter-laminar losses. Brazil: IEEE.

Mohamadi, A. E. (2011). A Collective approach towards green fourndries In South Africa-moving towards green foudnries in SA. Johannesburg: National Foundry Technology Network.

Sahay, A. B. (2014). Dealing with open fire in an underground coal mine vy ventilation control techniques. Journal of the Southern African Institute of Mining and Metallurgy , 114 (6), 447.

Ogunlade Davidson, H. W. (April 2006). Energy policies for sustainable development in South Africa. Cape-Town: Energy Research Centre, UCT.

Pandey, B. C. (2003). Laboratory study of channel gasification with stream-air blast in sub-bituminous coal from Pindra Raniganj coalfield. Minetech , 24 (6), 37-49.

Pasca, S. (2004). Particularities on numerical modeling of crucible induction furnace. Bucarest.

Wikipedia. (2014). Energy Efficiency. Wikipedia.

Y. Zhang, R. F. (1995). Effect of Carbonaceous Particles on Slag Foaming. Metallurgical and Materials Transactions B , 26B, 813.

Z.Z. Rasmeni, D. X. (2014). Analyse of energy efficien- cy and consumption in south african steel foundries. World Foundry Congress. Bilbao: World Foundry Congress.

Received 10 October 2014; revised 18 May 2015 